\title{
Housing Wealth and Wage Bargaining
}

\author{
Chris Cunningham and Robert R. Reed
}

\section{Working Paper 2012-20}

December 2012

\begin{abstract}
We examine the relationship between housing equity and wage earnings. We first provide a simple model of wage bargaining where failure leads to both job loss and mortgage default. Moreover, foreclosure generates disutility beyond selling a home. We test this prediction using nine waves of the national American Housing Survey. Employing a rich set of time and place controls, individual fixed effects, and an instrumental variable strategy, we find that people with an underwater mortgage command a significantly lower wage than other homeowners. This finding survives a number of robustness checks. We also include other determinants of "house lock" such as a favorable mortgage interest rate relative to the current rate and a capped property tax assessment, but we do not find these factors lower earnings. We conclude that negative equity matters because default is unpleasant or costly, not because it precludes an out-of-state job search.
\end{abstract}

JEL classification: D10, J30, R20

Key words: negative equity, wages, mortgage default

The authors gratefully acknowledge the generosity of Fernando Ferreira, Joseph Gyourko, and Joseph Tracy in sharing the code from their (2010) paper as well as excellent research support provided by Ellyn Terry. The views expressed here are the authors' and not necessarily those of the Federal Reserve Bank of Atlanta or the Federal Reserve System. Any remaining errors are the authors' responsibility.

Please address questions regarding content to Chris Cunningham, Research Department, Federal Reserve Bank of Atlanta, 1000 Peachtree Street, N.E., Atlanta, GA 30309-4470, 404-498-8977, chris.cunningham@atl.frb.org, or Robert Reed, Department of Economics, Finance, and Legal Studies, University of Alabama, Tuscaloosa, AL 35487, 205-348-8667, rreed@cba.ua.edu.

Federal Reserve Bank of Atlanta working papers, including revised versions, are available on the Atlanta Fed's website at frbatlanta.org/pubs/WP/. Use the WebScriber Service at frbatlanta.org to receive e-mail notifications about new papers. 


\title{
Housing Wealth and Wage Bargaining
}

\author{
Chris Cunningham \\ Federal Reserve Bank of Atlanta
}

\author{
Robert R. Reed \\ University of Alabama
}

September 16, 2012

\begin{abstract}
We examine the relationship between housing equity and wage earnings. We first provide a simple model of wage bargaining where failure leads to both job loss and mortgage default. Moreover, foreclosure generates disutility beyond selling a home. We test this prediction using nine waves of the national American Housing Survey. Employing a rich set of time and place controls, individual fixed effects and an instrumental variable strategy, we find that people with an underwater mortgage command a significantly lower wage than other homeowners. This finding survives a number of robustness checks. We also include other determinants of "house lock" such as a favorable mortgage interest rate relative to the current rate and a capped property tax assessment, but do not find these factors lower earnings. We conclude that negative equity matters because default is unpleasant or costly, not because it precludes out-of-state job search.
\end{abstract}

Keywords: Negative Equity, Wages, Mortgage Default

JEL Codes: D10, J30, R20

Cunningham, Federal Reserve Bank of Atlanta, 1000 Peachtree Street, NE, Atlanta, GA; Reed, Department of Economics, Finance, and Legal Studies, University of Alabma, 35487, (205) 3488667, rreed@cba.ua.edu. The views expressed in this paper do not necessarily reflect those of the Federal Reserve Bank of Atlanta or the Federal Reserve System. We gratefully acknowledge the generosity of Fernando Ferreira, Joseph Gyourko, and Joseph Tracy in sharing the code from their (2010) paper as well as excellent research support provided by Ellyn Terry. All errors are our own. 


\section{Introduction}

The recent housing bust has created a significant destruction of wealth in the U.S. economy. In a two-year time span beginning in November 2007, the median sales price of an existing home fell from $\$ 250,000$ to $\$ 210,000$ - a decline by more than $15 \%$. Evidence from the Case-Shiller Composite across 20 different metro areas is even more alarming. According to this index, housing prices peaked in April 2006 and continued to fall nearly 35\% until their apparent bottom in February of this year. Losses in individual housing markets have been staggering - for example, housing prices in Miami fell to less than half of their value from peak to trough. As a result of the loss of housing wealth, many homeowners fell "underwater" in terms of their equity position. That is, their mortgage debt became larger than the equity value of their homes. According to recent estimates from the fourth quarter of $2011,31.4 \%$ of homeowners in the United States are underwater, an increase from the same time period in 2010, yet 90 percent of underwater borrowers are current on their payments. ${ }^{1}$ This aversion to default may explain another unusual feature of the recovery, the continuing decline in real wages which are now 2 percent below where they were when the recession technically ended in June $2009 .^{2}$

There are a number of arguments for why homeowners may avoid "ruthless default" (or, strategic default). Some are based upon rational, economic arguments. Others are based on emotion or social norms. An underwater mortgage may still contain some option value if there is some chance that house prices could rise (Deng et. al, 2000). Even borrowers with little hope of price recovery may continue to pay their mortgage to avoid damage to their credit scores. A number of authors (see Foote et. al (2008), White (2009), and Bhutta (2010)) have stressed the disciplinary role of transactions costs as a deterrent from mortgage default. Third, it could also be that sentimental attachment to the home or the desire to maintain one's localized social capital

\footnotetext{
${ }^{1}$ See "Most Underwater Homeowners Still Paying Mortgages," by Ann Carns (New York Times, May 24, 2012).

${ }^{2}$ Fleck, Susan, John Glaser and Shawn Sprague, "The compensation-productivity gap: a visual essay," Monthly Labor Review, January 2011, p. 57-69 -- updated charts 6/12/2012.
} 
provides sufficient incentive to continue paying on a mortgage. Bhutta (2010), Guiso et. al.

(2009), and White (2010) contend that individuals face strong emotional or moral obligations to avoid default. Finally, credit quality could or could be perceived by workers to impact employability. ${ }^{3}$

The weight of these factors in a household's decision to default appears to be large. Based upon survey evidence, Guiso et. al. find that only $17 \%$ of households would strategically default if their equity shortfall reached $50 \%$ of the value of the home. Moreover, in their study of nonprime borrowers, Bhutta et. al. (2010) conclude that the median borrower will not walk-away until equity reached $62 \%$ below their home value. Therefore, homeowners will bear significant costs to remain in their homes and avoid mortgage default. In their study of the 1991 recession in Massachusetts, Foote et. al. (2008) find that only 6.4\% of homeowners with negative equity defaulted in the following three years. In particular, Foote et. al argue that negative equity is a necessary but not sufficient condition for default to occur and that a second "trigger" such as an employment shock is also required. However, this may also imply that remaining employed is more important to underwater workers and alters their bargaining position with the employer. If so, then exogenous shocks to house prices or mortgage markets (for example, Mian and Sufi, 2009) could affect labor markets. '

The objective of this paper is to show how housing equity affects labor market conditions. We first develop a simple model of wage bargaining common from the labor market search literature. The argument is pretty straightforward. Negative-equity homeowners engage in bargaining with a potential employer over their wage rate. Employees that fail to secure

\footnotetext{
${ }^{3}$ There is also some anecdotal evidence which indicates that employers may discriminate against workers in negative equity positions. Many companies run credit checks on job applicants. In response, one real estate observer noted: "I was having lunch with an executive head hunter the other day, and they were stating that corporations are picking their second or third choice for job applicants because they don't want to be stuck with someone who might be underwater with their home. Corporations can discriminate against you based on your financial status, and being in a home that's underwater is a perfectly good reason for an employer not to hire you." (Olick, June 3, 2011)
} 
employment lose their job and also default. Consequently, the value of employment for a worker in a negative equity position is larger than others who have significant housing wealth. As a result, "underwater" workers agree to work for lower wages. Thus, our model suggests that housing busts generate a significant negative feedback loop - house price depreciation leads to lower wages, and in turn, lower wages lead to greater housing losses.

We test this prediction using nine waves of the national American Housing Survey. The American Housing Survey (AHS) is particularly well suited for our question. First, the AHS is a nationally representative, house-based panel based upon information collected every two years. ${ }^{4}$ In comparison to other datasets such as the PSID, the AHS is much larger in scope - while the PSID contacts 8,000 families every other year, the AHS collects information from approximately 55,000 homes. As the AHS is a house-based panel, we are able to control for a number of important neighborhood amenities such as commuting time to work and whether it is in the central city. It also contains identifiers for metropolitan area that roughly correspond to the local labor market boundaries.

Most important, the AHS contains detailed mortgage data needed for understanding the labor market consequences of a home owner's equity position. We observe the purchase price, term, and mortgage balance from the first wave in which the current mortgage appears. From this information, we are able to determine each home owner's loan to value ratio (LTV). In our sample, we find that the average negative equity owner owes around $24 \%$ more than the equity value of their home. Moreover, the AHS contains additional mortgage information such as whether the home owner has an adjustable rate mortgage or a second mortgage. The presence of

\footnotetext{
${ }^{4}$ By comparison, Foote et. al. (2008) focus on a narrow geographic area in their study of the likelihood of default among negative equity borrowers. In their work, Foote et al use data from information collected on the Massachusetts housing market from 1990 - 1994.
} 
either mortgage arrangement is likely to contribute to a home owner's illiquidity, increasing the potential for default.

A number of empirical challenges exist to identifying a causal relationship between negative equity and wages. Declining area wages could lower housing prices and drive households underwater. If there is unobserved heterogeneity in the sample, we could observe some households borrowing more but also earning less without a causal relationship between the two variables. Finally, even if we control for labor and housing markets, idiosyncratic earnings shocks to households could lead them to defer maintenance on their home leading them to negative equity. We include household fixed effects to absorb unobserved time-invariant features of workers/borrowers and an instrumental variable for negative equity status. Across specifications, we find that being underwater in one's home is associated with between 5 and 9 percent decline in wages. Our richest and preferred specification suggests being underwater causes a 6 percent decline in real wages. These finding is robust to a number of checks that should reveal sensitivity to highly-localized wage and housing markets shocks or to negative equity resulting from deferred maintenance.

While our theory suggests that negative equity operates on wages because of the aversion to a job-loss induced default, a competing explanation is that negative equity impacts geographic mobility and ability to secure outside offers which could impact wage bargaining. To test for this, we interact negative equity with other determinants of household immobility like attachment to a particular home or neighborhood, the existence of a joint-location problem from dual earning households and duration in the current home. Negative equity appears to have the same effect on earnings for high- and low- mobility households. We also include other sources of "house lock" arising from nominal loss aversion, a favorable current mortgage rate and a favorable tax rate from California's Prop 13 assessment cap. While the threat of a nominal loss on the sale of the 
home is associated with negative wages, lock-in effects from property taxes and mortgage rates do not appear to lower wages. Thus, we believe the weight of evidence is more consistent with our hypothesis that an aversion to default weaken wage bargaining rather than house lock reduce outside wage offers.

The paper is organized as follows. In Section 2, we present our model of wage bargaining which demonstrates that workers with negative equity work for lower wages. Section 3 presents our econometric strategy. Section 4 describes the data and our primary results. Section 5 provides some robustness checks against misspecification and examines whether negative equity is impacting wages through immobility rather than bargaining. There is a brief conclusion.

\section{The Model}

We consider a labor market setting in which there are two different types of workers, distinguished by their net equity positions in their homes. This occurs because individuals purchased homes at different prices or because their neighborhood has experienced different price appreciation. Let $P^{0}$ represent the purchase price of the most recent group of homeowners. Other homeowners purchased homes at lower prices, $\lambda P^{0}$ as $\lambda$ is between 0 and 1 . Thus, the current cross-section of homeowners is heterogeneous, with different amounts of price appreciation. This may be due to the time period in which they became homeowners. Furthermore, assume that each homeowner made a down payment equal to $\Omega$. Therefore, if current market prices, $P^{1}$, are relatively low, then $\left(P^{1}-P^{0}\right)$ reflects the limited capital gains or potential losses that would occur among homeowners that are "underwater."

Assuming individuals have fixed rate mortgages, $(1+r)$ represents the gross mortgage rate.

Thus, taking into account the individual's resale value of their home, $\mathrm{P}^{1}-(1+\mathrm{r})\left(\mathrm{P}^{0}-\Omega\right)$ represents an 
underwater individual's negative equity position while $\mathrm{P}^{1}-(1+\mathrm{r})\left(\lambda \mathrm{P}^{0}-\Omega\right)$ represents a standard homeowner's positive equity position.

Our objective is to use a simple model of Nash bargaining between a worker and a job vacancy to explain how an individual's housing equity position can influence labor market activity, such as an individual's wage rate. As is standard in the labor search literature, wage bargaining between a worker and a firm occurs in a setting with complete information. In particular, the firm observes information about a worker's equity position. In practice, reasonable estimates for an applicant's housing equity would not be difficult to determine. For example, Mian and Sufi (2009) construct zipcode-level house price data from Fiserv's Case Shiller Weiss indices. Information about the number of number of foreclosures at the zip-code level may also be obtained from RealtyTrack.com. Moreover, survey evidence from the Society for Human Resource Management (2010) indicates that as many as $60 \%$ of organizations utilize credit checks for candidates of select jobs. An individual's payment history for their mortgage would be included in a credit check. Furthermore, the presence of a home equity line of credit and the number of mortgages could also be observed.

In the bargaining game, workers have two choices. First, they must decide whether to accept a job with a firm. Second, they must decide whether to sell their homes, settle their mortgage obligations, or default. Should an individual default, they will incur a subjective cost $\delta$ $>0 .^{5}$ Any worker may choose to default. We assume that wages of workers are determined by symmetric Nash bargaining. ${ }^{6}$

\footnotetext{
${ }^{5}$ This may reflect the transactions costs associated with default or the emotional costs due to loss of social capital. In this manner, our model follows previous work such as Foote et. al. (2008) and Bhutta et. al. (2010). However, our innovation is that we incorporate the subjective costs of default in a labor market context.

${ }^{6}$ Symmetric Nash bargaining is often utilized in wage determination in labor search models. However, the qualitative results from our analysis would always hold as long as the firm had some degree of bargaining power. That is, the implications of housing equity for wages are quite robust.
} 
We study the equilibrium choices of each group of agents through a process of backwards induction. Consider an average homeowner who currently does not have a job. Their net equity position, $\mathrm{P}^{1}-(1+\mathrm{r})\left(\lambda \mathrm{P}^{0}-\Omega\right)$, is positive and therefore exceeds the loss suffered through default, $-\delta$

We now turn to the repayment decision of average homeowners who are employed earning wage $w^{1}$. Should a worker choose to repay the loan, the net gain from repayment is $w^{1}+\mathrm{P}^{1}-(1+\mathrm{r})\left(\lambda \mathrm{P}^{0}-\Omega\right)$. If they default, the net gain is: $w^{1}-\delta$. Thus, all above water homeowners will settle their mortgage debt.

We next consider the choices among underwater homeowners. Underwater homeowners without jobs do not have any option except to default. By comparison, underwater homeowners with jobs may choose to default or settle their mortgage obligations. If they choose to settle, their net income would be: $w^{0}+\mathrm{P}^{1}-(1+\mathrm{r})\left(\mathrm{P}^{0}-\Omega\right)$. Should they choose to default, their net utility is $-\delta$.

Lemma 1. The decision to default balances the reduced capital gains against the subjective loss incurred from default:

$$
P_{1}>(1+r)\left(P_{0}-\Omega\right)-\delta
$$

Thus, if the subjective cost of default is sufficiently high, workers in a negative equity position would choose settle their mortgage obligations. ${ }^{7}$ Only unemployed workers would default.

We will now demonstrate that an individual's net equity position can have important implications for their level of wages. Conditional on the settlement of mortgages, we can

\footnotetext{
${ }^{7}$ Recall Guiso et. al. (2011) find only a small number of borrowers would strategically default even if their equity shortfall reached $62 \%$ below their home value. Moreover, Foote et. al. (2008) and Bhutta et. al (2010) conclude that negative equity borrowers rarely default.
} 
determine each worker's wage rate through symmetric Nash bargaining. We begin by considering the level of wages paid to average homeowners.

If an average homeowner turns down the wage offer, $w^{1}$, they can still settle their mortgage debt due to the capital gains in housing prices to generate net income equal to: $\mathrm{P}^{1}-(1+\mathrm{r})\left(\lambda \mathrm{P}^{0}-\Omega\right)$. In contrast, if they work, they generate income in the labor market and the housing market: $w^{1}+\mathrm{P}^{1}-(1+r)\left(\lambda \mathrm{P}^{0}-\Omega\right)$. Thus, for workers who have positive equity, their gains from accepting a job offer are completely independent of their equity position in their homes: $w^{1}$. Should a firm hire the worker and generate revenue $y$, the firm's net gain is: $y-w^{1}$. Consequently, wages among average homeowners only depend on revenues generated by the firm: $w^{1}=1 / 2 y$.

By comparison, underwater homeowners rely on their labor market income to settle their underwater mortgage obligations. If they reject a wage offer, they will be forced to default and incur the subjective cost, $\delta$. However, if they accept a wage offer, they would obtain utility: $w^{0}+\mathrm{P}^{1}-(1+\mathrm{r})\left(\lambda \mathrm{P}^{0}-\Omega\right)$. Therefore, we present:

Lemma 2. Wages among underwater homeowners are lower than average homeowners so that they can avoid the subjective cost of mortgage default:

$$
w_{0}=(1 / 2)\left[y+(1+r)\left(P_{0}-\Omega\right)-P_{1}-\delta\right] \text {. }
$$

Wages among underwater homeowners depend on three important factors: (i) labor market conditions, (ii) housing market conditions and (iii) the subjective cost of default. As we emphasize in the introduction, the available evidence suggests there is a strong desire by homeowners to avoid mortgage default. Consequently, the subjective cost of default $(\delta)$ is likely to be large. However, should the negative-equity worker accept employment, their net income will be lower than other workers since they must settle their mortgage obligations. Consequently, 
the interest rate and housing price will impact earnings. Though our prior is that the subjective cost of default should dominate earnings, it is an empirical question to test in the balance of the paper.

\section{Econometric Specification}

We estimate a conventional labor market earnings equation where real earnings, $w_{i t}$, are regressed on a set of controls for educational attainment, demographics, and household composition, $X_{i t}$, and a set of time and space fixed effects to absorb exogenous sources of variation that might influence both earnings and house prices, $L_{j} \times Y_{t}$. We also include our

variable of interest, which in most specifications is a dummy, $D^{\text {negative equity }}$, indicating if current remaining principal, $p_{t}$, exceeds the current market price of the home, $v_{t}$.

$$
\ln \left(w_{i t}\right)=X_{i t}^{\prime} \beta+\left(L_{j} \times Y_{t}\right)^{\prime} \delta+\theta D_{i t}^{\text {negative equity }}+\varepsilon_{i t}
$$

Formally, our null hypothesis is: $H_{0}: \theta \geq 0$ and our alternative hypothesis is $H_{a}: \theta<0$. In the specification above, the parameter $\theta$ captures the effect, (roughly) in percentage terms, of negative equity on one's current wage. There are three serious econometric challenges to identify a causal link between housing equity which we address in turn below.

\subsection{Simultaneity in labor and housing markets}

First, and most paramount, there is likely to be a simultaneity problem when looking at metropolitan labor market conditions and house prices. Our central hypothesis is that having an underwater house lowers a worker's earnings. However, falling area wages, perhaps because of a shock to local firms or industry could lower house prices and drive workers underwater on their mortgage. We overcome this problem by relying on within-labor-market variation in wages and 
house prices. Specifically, we include ever richer set of location fixed effects interacted with year dummies. In our initial specification we interact census region and year, but then quickly shift to the Standard Metropolitan Statistical Area (SMSA) a measure of city area that is a precursor to the more commonly used MSA. Finally, we get an even finer geography, by splitting the MSAs into urban (defined as residing within the center city) and suburban regions. In these specifications, all common variation in house prices and wages is absorbed by the fixed effect. This is the finest geography we can obtain using the public-use AHS. However, as a robustness check, we also limit our sample to workers that commute more than the national median distance. If localized labor market shocks within a metropolitan area are also affecting localized housing markets, then the effect of negative equity on wages for homeowners should not impact the wages of negative equity homeowners that work on the other side of town. As will been seen, workers with long commutes are no less affected by negative equity than those with short commutes.

\subsection{Unobserved Household Heterogeneity}

A second challenge to the researcher is that we do not fully observe worker characteristics that affect both earnings and indebtedness. For example, a person with more skills or ability may command a higher salary but also save up more for a larger down payment or secure a lower interest rate from the lender. Alternatively, a more financially savvy person (or simply a better bargainer) might command a higher salary but also negotiate better mortgage terms. To address this competing explanation we decompose the error term into an individual error component, $u_{i}$, and a remaining idiosyncratic term such that $\varepsilon_{i t}=u_{i}+e_{i t}$. Thus, our estimating equation is transformed into:

$$
\ln \left(w_{i t}\right)=X_{i t}^{\prime} \beta+\left(L_{j} \times Y_{t}\right)^{\prime} \delta+\theta D_{i t}^{\text {negative equity }}+u_{i}+e_{i t}
$$


where the time-invariant individual determinant of wage is replaced with a fixed effect. Thus, in the above specification, identification rests on changes in individual earnings and negative equity status over time.

\subsection{Simultaneity in earnings and outstanding principal}

Finally, there is a second inter-temporal simultaneity problem at the household level. A worker suffering lower earnings may seek a home equity line of credit or a cash-out re-financed mortgage. Conversely, a household that experiences a positive income shock may choose to pay down their mortgage. If house prices should subsequently fall, the worker with higher earnings may be less likely to end up underwater. To prevent this type of reverse causality from contaminating our results we pursue an instrumental variable strategy. Recall that our dummy variable of interest, $D^{\text {negative equity }}=1$ if $p_{t}>v_{t}$, where $p_{t}$ is the remaining principal on the loan and $v_{t}$ is the current market value. Thus, to construct our instrument we create a synthetic mortgage that gives every homeowner that took an initial mortgage at the time of purchase the same basic mortgage. The remaining principal on a mortgage $p_{t}$, in year $t$, is derived from the following formula:

$$
p_{t}=b_{y}\left[\frac{(1+i)^{T}-(1+i)^{(t-y) / 12}}{\left((1+i)^{T}-1\right)}\right]
$$

where, $b_{y}$, is the amount initially borrowed, the duration (or term) of the mortgage is $T$, and the interest rate, $i$. To create our instrument, we impose the following rules: 1) all borrowers take a conventional 30 year amortizing mortgage, 2) there are no pre-payments or refinancing, 3) all 
borrowers receive the average prevailing interest rate $^{8}$ and 4) all homeowners borrow 80 percent of the purchase price. ${ }^{9}$ We then estimate this synthetic measure of principal, $\tilde{p}_{t}$, and create our instrument for negative equity, $\tilde{D}_{t}^{\text {negative equity }}=1$ if $\tilde{p}_{t}<v_{t}$. Thus, our instrument should be correlated with negative equity status arising from house price shocks and/or short duration in the home but uncorrelated with any propensity to extract (or increase) equity.

We, and perhaps the reader, anticipate a number of other competing hypotheses for why negative equity appears to be correlated with slower wage growth. However, we address these concerns by subjecting our results to a series of robustness checks and or by including variables associated with these competing explanations directly into the model to see whether they obviate our central results at the end of the paper.

\section{Data and Results}

We test our model by examining the relationship between negative equity and wages in the national sample of the American Housing Survey (AHS). The AHS surveys the same structure every two years. We limit the sample to respondents that own a single family home and earned a real wage of at least 10,000 dollars which we select as an ad hoc indicator of being meaningfully in the labor force. ${ }^{10}$ The sample is limited to the years between 1985-2003 to avoid the employment shocks associated with the post-Lehman financial crisis and the more exotic mortgages that became popular in the second half of the last decade. There was also a change in the earnings survey starting in 2005 that we wish to avoid.

\footnotetext{
${ }^{8}$ We use the mortgage rate from Freddie Mac's MIRS: Terms on conventional single-family mortgages, annual national averages, all homes (table 9.)

${ }^{9}$ Our results are robust to the use of a less proscribed mortgage instrument. For example keeping all other terms of the mortgage the same as the actual mortgage but giving the household the prevailing interest rate, or assuming a household took an $80 \%$ LTV loan but allowing households to refinance.

${ }^{10}$ In constant 2007 dollars deflated by the all urban workers CPI-U index. The estimates presented in the following section are robust to lower wage cut-offs.
} 
The dependent variable is the natural log of real wages reported by the respondent. We exclude spousal income, so that we have one observation per household per year. Missing wages that were interpolated using a hot-decking procedure by the AHS are dropped from the sample. Education is based on the years of completed school. When flagged with a dummy variable, the spousal work variable indicates that the spouse earned at least 10,000 dollars as well. Age is included as a third-order polynomial.

Negative equity is measured as the current market price less outstanding mortgage principal. To determine principal we follow Schwartz (2006) by using the mortgage rate, principal and term from the first wave that we observe the current mortgage. However, we use the current wave reported values for calculating the second mortgage because we are less confident in our ability to track second mortgages across time. ${ }^{11}$ We then calculate the current mortgage balance for each mortgage, sum them and subtract from the owner's current assessment of home value to determine equity. ${ }^{12}$ We rely on self-reported home value because recent work by Wallace (2011) suggests that these indexes underestimate the idiosyncratic price changes within geographies over time and would thus tend to under-estimate the share of households with negative equity. Mian and Sufi (2009) also find evidence of significant inconsistency between within zipcode-level price growth and within-MSA price growth. Finally, because we will fully absorb all intermetropolitan, inter-year variation in wages, we simply can't identify an effect of negative equity on wages without some within labor market variation in house price growth. Descriptive statistics for our primary sample of 40,579 person-year observations as well as the subset of households with negative equity are reported in Table 1.

\footnotetext{
${ }^{11}$ We do not examine $3^{\text {rd }}$ and higher mortgages because these variables are not fully tracked within the AHS. We ultimately rely on an instrumental variables approach that should accommodate this measurement error.

${ }^{12}$ Balance=loan amount $\left[\frac{(1+i)^{T}-(1+i)^{(t-y) / 12}}{\left((1+i)^{T}-1\right)}\right]$, where, $T$ is the term of the mortgage in months, $i$, the interest rate, $t$ the current year and $y$ the year the mortgage was originated.
} 


\subsection{Initial Results with space and year fixed effects}

The first column of Table 1 provides the coefficient estimates when we include controls for the labor market, respondent education and other demographic and household variables and fixed effects for year, SMSA, and whether the house was urban (in the central city) or suburban. ${ }^{13}$ This baseline specification thus absorbs all time-invariant variation in house prices and wages across cities. The year fixed effects also absorb any purely inter-temporal variation in wages and prices. Finally, for the initial specification we also specify yearxcensus region fixed effects. Our coefficient estimate on the negative equity dummy, $\hat{\theta}$, is negative and significant at the one percent level and implies that having mortgage debt that exceeds the current home price lowers one's current wage by 7.3 percent, a fairly large effect, equivalent to increasing the metropolitan unemployment rate by 1.5 percentage points.

In column 2 of Table 1 we switch to an SMSAxyear fixed effect. In this specification all city-wide changes in wages and house prices (and city unemployment rate) are absorbed by the vector dummy variables. Surprisingly, these additional control variables lead to little change of our estimate of the impact of negative equity. In column 3, we present the coefficient estimates when we create an even finer geography by creating a separate dummy variable for each central city and its suburbs by also interacting the "metro status" indicator (metroxSMSAxyear). Using these richer sets of fixed effects lowers our estimate of the impact of negative equity on wages modestly to -6.6 percent but remains statistically different from zero at the one percent level. This is the finest geographic we can identify in the public-use AHS and should absorb the effect of general labor market conditions on house prices. However, as a robustness check, in column 4 we

\footnotetext{
${ }^{13} 687$ households in the AHS were deemed "rural" after 1995 but still match to two SMSAs (2160 and 6160.) We reclassify these households as "suburban" and leave them in the sample but the coefficient estimates are little changed if we exclude the observations; estimates are available from the authors upon request.
} 
limit the sample to respondents that commute more than 10 miles to work. This is the median commute distance in our sample. If more localized labor market shocks are affecting house prices, rather than negative equity impacting wage bargaining, we should see less or no effect of negative equity on commuters whose employment market is removed from their housing market. However, when we limit the sample to long distance commuters, the negative equity dummy has the same or even slightly larger impact on wages. In column 5, we include the dollar value of negative equity. Note that in this specification, it is the amount of negative equity that impacts wages. Every $\$ 10,000$ increase in negative equity, is associated with a $0.7 \%$ reduction in earnings.

\subsection{Household Fixed Effect}

Recall that negative equity is measured using the estimated remaining principal of both first and second mortgages so the second mortgage indicator may tell us something about how (and perhaps when) a household borrows, but not their total indebtedness. Note that the presence

of complex mortgage arrangements such as an ARM or a $2^{\text {nd }}$ mortgage positively affects an individual's earnings. At first glance, the positive correlation may seem counterintuitive. Yet, we believe it highlights how mortgage-credit conditions among borrowers affect their work incentives. The presence of either mortgage arrangement is likely to contribute to a home owner's illiquidity, increasing the potential for default. Consequently, as these workers are more likely to strategically default, they would not choose to settle for lower wages. Yet, our coefficient for negative equity remains of similar magnitude and statistically significant at standard cut-offs.

Even controlling for initial mortgage conditions, unobserved characteristics about the borrower may cause them to be more likely to end up with negative equity and experience lower earnings growth. In column 2 we present the coefficient estimates when we also include a full set of individual fixed effects. In this specification, identification relies solely on variation in 
individual earnings over time and across negative equity status. While individual fixed-effects reduce the magnitude of the coefficient estimate to -.053, it remains statistically and economically significant.

\subsection{Two-Stage Estimation}

The previous specification, controlled for time-invariant unobserved characteristics of the worker. However, there is still the possibility that income shocks could work in reverse to push a household underwater if an income shock forced them to take out a second mortgage or take a cash-out refinance of their mortgage. In columns 3 and 4 we present the coefficient estimates when we instrument for negative equity status using the synthetic mortgage measure described in section 3.3. Column 3 presents the results from the IV estimation without household fixed effects and column 4 includes them. The first stage which includes all covariates in the second stage, as well as our synthetic negative equity indicator is not shown is highly significant. ${ }^{14}$ Note that the instrumented measure of negative equity is actually greater in magnitude than previous estimates (without individual fixed effects) suggesting that our measure of negative equity may suffer from measurement error. Reintroducing the individual fixed-effect (column 4) yields an effect of -0.06 of negative equity on wages. We thus reject our null hypothesis that negative equity does not lower wages in favor of the alternative that they do. This is our preferred specification.

\subsection{Depreciation}

Rather than extract equity from one's home via the financial market, a homeowner experiencing a wage shock might stop maintaining the house and extract equity through depreciation. Ideally, we would have a good instrument for home value, but as we rely on intrametropolitan variation in wages and prices without finer geocodes, we are unaware of a satisfactory one, and must instead rely on self-reported values. However, as robustness check

\footnotetext{
${ }^{14}$ Results are available from the authors upon request.
} 
against simultaneity in wages and depreciation, we stratify the sample by high- and low- land price cities. The intuition for the test is that while construction cost -and by extension-- structure value is relatively constant across cities, land values are quite heterogeneous. Thus, a policy of deferred maintenance is more likely to cause equity to fall below principal when structure value comprises most of the homes worth than in a high-land price city were most of the home value cannot depreciate. While we lack a direct measure of land value we calculate total growth in constant-quality house prices between January 1976 and January 1995 (roughly halfway through our sample period) using Core-Logic's repeat sales house price index. The coefficient estimates are presented in columns 5 and 6 of Table 3. Surprisingly, being underwater in a low-land value city has no statistically significant effect on one's wages, but being underwater in a high-land value city does. This finding gives us confidence that negative equity in our sample is arising from exogenous, localized housing market shocks and not through deferred maintenance. The balance of the paper is devoted to applying additional robustness checks and accommodating competing explanations.

\section{Competing Explanations and Additional Robustness Checks}

Recent work by FGT (2010) finds that negative equity lowers mobility, a phenomenon referred to as "house lock." 15 If underwater homeowners are more averse to moving then they may limit their out-of-market job search and increase the chance of unemployment. By extension, the inability to credible search for work beyond the local labor market could also weaken an employee's wage bargaining position. ${ }^{16}$ In this section, we introduce other barriers to inter-

\footnotetext{
${ }^{15}$ FGT (2010) point out that “...we need to begin considering the consequences of lock-in and reduced mobility because they are quite different from those associated with default and higher mobility." (p.34). It should be noted that in attempt to replicate the results of FGT(2010), Schulhofer-Wohl (2012) finds that negative equity slightly increases mobility if one treats temporary movers (inter-wave absences in the AHS) as mobile. FGT (2011) reconfirms their result that negative equity reduces permanent moves.

${ }^{16}$ FGT (2010) do not make this inference.
} 
metropolitan mobility to see whether otherwise more mobile households are more impacted by negative equity when negotiating wages with their current employer. We then include other sources of housing related immobility in the model to see whether they directly impact wages.

We first look at households that may have less personal attachment to their current home. The AHS asked respondents why they moved to their current (sampled) home the first time the household appears in the survey. Respondents that replied that they moved because of a job transfer, to be nearer work or for other financial and employment reasons might be more amenable to moving again and thus more likely to experience a decline in earnings if they experience house lock. We include a dummy for these households and interact it with the negative equity dummy in the regression results presented in column 1 of Table 4 . For all specifications in Table 4 we include use the synthetic measure of negative equity in the regressions. Households that previously moved for work appear to earn a premium relative to other households, but are not disproportionately impacted by having negative equity.

Another source of immobility might be the joint-location problem that confronts dualearner households. In column 2 of Table 4 we present results when we interact the dummy for working spouse with the negative equity indicator. Having a working spouse is associated with lower respondent earnings, but again, doesn't appear to mitigate the impact of negative equity.

Previous work by Engelhardt (2003), found that the prospect of a nominal loss from the sale of a home deterred mobility for a sample of younger owners. In column 3 of Table 4 we present coefficient estimates with an indicator for nominal loss. Households with homes worth less than the purchase price do appear to earn less than others however the effect of negative equity on earnings remains statistically different from zero, though a bit smaller with a parameter estimate of .066 . 
House lock could also be generated by changes in prevailing mortgage rates if the (fixed) mortgage rate on the current house is low compared to prevailing rates. This could generate a lock-in effect because mortgages are not portable and moving from a house with a low rate would require financing the purchase of a new house with a new mortgage at the higher current rate (Quigley 1987, FGT 2010). Another source of house lock may arise from limits on property tax assessments. The first and most studied being California's Proposition $13 .{ }^{17}$ Under this law, growth in assessed value is capped and can only grow at a rate well below market growth, but only resets when a home sells. Thus, a homeowner would experience a large increase in their property tax if they bought a home of similar value in the same state. The differential tax treatment for recent and long-staying homeowners raises the cost of moving and should deter moving (O’Sullivan, Sheffrin and Sexton, 1995). Empirical work on Prop-13 in California (Ferreira, 2009) and a similar law in Florida (Ihlanfeldt, 2011), find evidence consistent with this hypothesis.

In columns 4 and 5 we add, in turn, FGT's measures for mortgage lock-in and Prop-13 lock-in. While these values may lower household mobility, they do not appear to negatively impact earnings. Indeed, both the mortgage lock-in and assessment cap lock-in effects are positively associated with earnings. We're not sure what exactly explains the positive relationship. The latter result may arise from greater exposure to the strong wage growth experienced by California. The mortgage rate effect may be the result of unobserved heterogeneity. Only high earning households are able to purchase a home during recessions when house prices are low. Nevertheless, even after incorporating these factors which influence mobility, the coefficient for negative equity remains the same with a high degree of statistical significance. In summary, we find that negative equity appears to have a similar impact on wages

\footnotetext{
${ }^{17}$ A number of states now limit the growth rate in a property’s assessed value (Hoyt et. al., 2011).
} 
for immobile households as it does for mobile ones. Also, while households that would suffer a nominal loss if they moved appear to earn lowers wages, other sources of immobility from the property tax or mortgage rates do not appear lower wages.

\section{Conclusions}

One of the striking features of the 2008 recession and the recovery has been weak wage growth combined with strong firm earnings. We offer one explanation that is consistent with the phenomenon; negative equity weakens a worker's bargaining power. Testing this prediction in the AHS, we find that people with an underwater mortgage command a significantly lower wage than other homeowners. This finding is robust to interacted time and location fixed effects and individual fixed effects. While we cannot exclude all competing hypothesis, we find little evidence that negative equity is the result of deferred maintenance, or changes in loan terms, or borrowing. We also include other determinants of "house lock" such as a favorable fixed mortgage interest rate relative to the current rate and a capped property tax assessment, but do not find these factors lower wages. Thus, we believe our results are consistent with a natural extension of the findings of Foote et. al. (2008) that a household under water will attempt to keep their home unless they suffer an employment shock, and thus choose to avoid an employment shock by bargaining less vigorously over wages. 


\section{References}

Bhutta, Neil, Jane Dokko, and Hui Shan, 2010. "The Depth of Negative Equity and Mortgage Default Decisions." Working Paper, Finance and Economics Discussion Series, Federal Reserve Board, WP 2010-35.

Chan, Sewin, 2001. "Spatial Lock-in: Do Falling House Prices Constrain Residential Mobility?" Journal of Urban Economics, 49 (3), 567-586.

Engelhardt, Gary V. 2003. "Nominal Loss Aversion, Housing Equity Constraints, and Household Mobility: Evidence from the United States." Journal of Urban Economics 53, no. 1: 171195.

Deng, Y., Quigley, J. M. and Van Order, R. (2000), Mortgage Terminations, Heterogeneity and the Exercise of Mortgage Options. Econometrica, 68: 275-307.

Ferreira, Fernando. 2010. "You Can Take It with You: Proposition 13 Tax Benefits, Residential Mobility, and Willingness to Pay for Housing Amenities.” Journal Of Public Economics 94, no. 9-10: 661-673.

Ferreira, Fernando, Joseph Gyourko, and Joseph Tracy. 2010. "Housing Busts and Household Mobility." Journal of Urban Economics 68 (1), 34-45.

Ferreira, Fernando, Joseph Gyourko, and Joseph Tracy. 2011. "Housing Busts and Household Mobility: An Update.” NBER Working Paper 17405.

Fleck, Susan, John Glaser and Shawn Sprague, "The Compensation-productivity gap: a visual essay," Monthly Labor Review, January 2011, p. 57-69 -- updated charts 6/12/2012 bls.gov/lpc.

Foote, Christopher L., Kristopher Gerardi, and Paul S. Willen, 2008. "Negative Equity and Foreclosure: Theory and Evidence." Journal of Urban Economics 64, 234-45.

Guiso, Luigi, Paola Sapienza, and Luigi Zingales. 2009. "Moral and Social Constraints to Strategic Default on Mortgages.” NBER WP \#15145, July.

Hoyt, William H., Paul A. Coomes, and Amelia M. Biehl. 2011. "Tax Limits and Housing Markets: Some Evidence at the State Level.” Real Estate Economics, 39, (1), 97-132.

Ihlanfeldt, Keith R., 2011. "Do Caps on Increases in Assessed Values Create a Lock-In Effect? Evidence from Florida's Amendment One.” National Tax Journal, 64, (1), 7-25.

Mian, Atif, and Amir Sufi, 2009. "The Consequences of Mortgage Credit Expansion: Evidence from the U.S. Mortgage Default Crisis." Quarterly Journal of Economics November, 1449-1496.

Olick, Diana. "Your Home as Corporate Housing: It Just May Get You a Job.” June 3, 2011. Available at: www.cnbc.com/id/43269087.

O'Sullivan, Arthur, Steven M. Sheffrin, and Terri A. Sexton.,1995, "Property Taxes, Mobility, and Home Ownership." Journal of Urban Economics 37 (1), 107-29.

Nagy, John, 1997. "Did Proposition 13 Affect the Mobility of California Homeowners?” Public Finance Review, 25 (1), 102-116.

Quigley, John M., 1987. "Interest Rate Variations, Mortgage Prepayments and Household Mobility." The Review of Economics and Statistics, 69 (4), 636-643. 
Schulhofer-Wohl, Sam, 2012, "Negative Equity Does Not Reduce Homeowners' Mobility" Federal Reserve Bank of Minneapolis Quarterly Review, 35(1), 2-14.

Schwartz, Allie (2006), "Household Refinancing Behavior in Fixed Rate Mortgages," Working Paper, Harvard University.

Wallace, Nancy, 2011. "Real Estate Price Measurement and Stability Crises” IRES Working Paper Series.

Wasi, Nada, Michelle J. White, Steven M. Sheffrin, and Fernando Vendramel Ferreira, 2005. "Property Tax Limitations and Mobility: Lock-In Effect of California's Proposition 13." In Burtless, Gary A., and Janet Pack (eds.), Brookings-Wharton Papers on Urban Affairs, Issue 6, 59-88. Brookings Institution Press, Washington, DC.

White, Brent, 2009. "Underwater and Not Walking Away: Shame, Fear, and the Social Management of the Housing Crisis.” Arizona Legal Studies Discussion Paper \#09-35, 2009. 
Table 1: Summary statistics

\begin{tabular}{|c|c|c|}
\hline variables & $\begin{array}{c}\text { (1) } \\
\text { full } \\
\text { sample }^{1}\end{array}$ & $\begin{array}{c}(2) \\
\text { negative equity }{ }^{2}\end{array}$ \\
\hline $\ln \left(\right.$ real wage $\left.{ }^{3}\right)$ & $\begin{array}{c}10.91 \\
(0.599)\end{array}$ & $\begin{array}{c}10.78 \\
(0.583)\end{array}$ \\
\hline married & $\begin{array}{c}0.715 \\
(0.451)\end{array}$ & $\begin{array}{c}0.650 \\
(0.477)\end{array}$ \\
\hline $\begin{array}{l}\text { education: } \\
\text { high school }\end{array}$ & $\begin{array}{c}0.255 \\
(0.436)\end{array}$ & $\begin{array}{c}0.225 \\
(0.418)\end{array}$ \\
\hline some college & $\begin{array}{c}0.270 \\
(0.444)\end{array}$ & $\begin{array}{c}0.316 \\
(0.465)\end{array}$ \\
\hline college & $\begin{array}{c}0.247 \\
(0.431)\end{array}$ & $\begin{array}{c}0.242 \\
(0.429)\end{array}$ \\
\hline at least one year of graduate school & $\begin{array}{c}0.173 \\
(0.379)\end{array}$ & $\begin{array}{c}0.140 \\
(0.347)\end{array}$ \\
\hline white & $\begin{array}{c}0.839 \\
(0.368)\end{array}$ & $\begin{array}{c}0.761 \\
(0.427)\end{array}$ \\
\hline male & $\begin{array}{c}0.743 \\
(0.437)\end{array}$ & $\begin{array}{c}0.721 \\
(0.449)\end{array}$ \\
\hline age & $\begin{array}{c}42.08 \\
(8.824)\end{array}$ & $\begin{array}{c}40.08 \\
(8.443)\end{array}$ \\
\hline spouse works & $\begin{array}{c}0.532 \\
(0.499)\end{array}$ & $\begin{array}{c}0.482 \\
(0.500)\end{array}$ \\
\hline number of persons in household & $\begin{array}{c}3.220 \\
(1.510)\end{array}$ & $\begin{array}{c}3.147 \\
(1.654)\end{array}$ \\
\hline mortgage lock-in ${ }^{4}$ & $\begin{array}{c}0.201 \\
(0.558)\end{array}$ & $\begin{array}{c}0.179 \\
(0.544)\end{array}$ \\
\hline prop-13 lock-in ${ }^{4}$ & $\begin{array}{c}0.216 \\
(0.749)\end{array}$ & $\begin{array}{l}0.0667 \\
(0.313)\end{array}$ \\
\hline
\end{tabular}

${ }^{1}$ Sample consists of respondents earning at least $\$ 10,000$ residing in a single-family, owneroccupied home.

${ }^{2}$ Negative equity status is determined based on self-assessed home value, and current principal calculated based of features of the mortgage(s) when the mortgage is first observed in the AHS, consistent with the findings of Schwartz (2006).

${ }^{3}$ The dependent variable is log real annual wage where real annual wage is calculated using the full urban workers CPI.

${ }^{4}$ We kindly thank the authors of FGT(2010) for sharing these variables. 
Table 2: Negative equity and earnings controlling for simultaneity between housing and labor markets

\begin{tabular}{|c|c|c|c|c|c|}
\hline & $\begin{array}{l}\text { (1) } \\
\text { region } \times \text { year } \\
\text { fixed effects }\end{array}$ & $\begin{array}{c}(2) \\
\text { SMSA×year } \\
\text { fixed effects }\end{array}$ & $\begin{array}{c}(3) \\
\text { SMSA×metro } \\
\text { status } \times \text { year } \\
\text { fixed effects }\end{array}$ & $\begin{array}{c}\text { (5) } \\
\text { negative } \\
\text { equity and } \\
\text { long } \\
\text { commuting } \\
\text { distance }^{3}\end{array}$ & $\begin{array}{c}\text { (4) } \\
\text { negative } \\
\text { equity in } \\
\text { (10k) dollars }\end{array}$ \\
\hline$D^{\text {negative equity }}$ & $\begin{array}{l}-0.073 \\
(0.021)\end{array}$ & $\begin{array}{l}-0.073 \\
(0.022)\end{array}$ & $\begin{array}{l}-0.066 \\
(0.022)\end{array}$ & $\begin{array}{l}-0.071 \\
(0.032)\end{array}$ & $\begin{array}{c}0.004 \\
(0.022)\end{array}$ \\
\hline $\begin{array}{l}\text { unemployment rate } \\
\text { negative equity in } 10 \mathrm{Ks}\end{array}$ & $\begin{array}{l}-0.048 \\
(0.361)\end{array}$ & -- & -- & -- & $\begin{array}{l}-- \\
-0.008 \\
(0.0004)\end{array}$ \\
\hline married & $\begin{array}{c}0.137 \\
(0.012)\end{array}$ & $\begin{array}{c}0.138 \\
(0.012)\end{array}$ & $\begin{array}{c}0.136 \\
(0.012)\end{array}$ & $\begin{array}{c}0.121 \\
(0.019)\end{array}$ & $\begin{array}{c}0.124 \\
(0.012)\end{array}$ \\
\hline education $^{1}$ & & & & & \\
\hline high school & $\begin{array}{c}0.247 \\
(0.015)\end{array}$ & $\begin{array}{c}0.251 \\
(0.015)\end{array}$ & $\begin{array}{c}0.250 \\
(0.016)\end{array}$ & $\begin{array}{c}0.230 \\
(0.023)\end{array}$ & $\begin{array}{c}0.237 \\
(0.015)\end{array}$ \\
\hline some college & $\begin{array}{c}0.386 \\
(0.015)\end{array}$ & $\begin{array}{c}0.390 \\
(0.016)\end{array}$ & $\begin{array}{c}0.389 \\
(0.016)\end{array}$ & $\begin{array}{c}0.342 \\
(0.023)\end{array}$ & $\begin{array}{c}0.370 \\
(0.016)\end{array}$ \\
\hline college & $\begin{array}{c}0.595 \\
(0.016)\end{array}$ & $\begin{array}{c}0.599 \\
(0.016)\end{array}$ & $\begin{array}{c}0.597 \\
(0.016)\end{array}$ & $\begin{array}{c}0.561 \\
(0.023)\end{array}$ & $\begin{array}{c}0.561 \\
(0.016)\end{array}$ \\
\hline $\begin{array}{l}\text { at least one year of } \\
\text { graduate school }\end{array}$ & $\begin{array}{c}0.734 \\
(0.017)\end{array}$ & $\begin{array}{c}0.736 \\
(0.017)\end{array}$ & $\begin{array}{c}0.733 \\
(0.017)\end{array}$ & $\begin{array}{c}0.689 \\
(0.025)\end{array}$ & $\begin{array}{c}0.690 \\
(0.017)\end{array}$ \\
\hline white & $\begin{array}{c}0.173 \\
(0.010)\end{array}$ & $\begin{array}{c}0.175 \\
(0.010)\end{array}$ & $\begin{array}{c}0.175 \\
(0.010)\end{array}$ & $\begin{array}{c}0.195 \\
(0.014)\end{array}$ & $\begin{array}{c}0.162 \\
(0.010)\end{array}$ \\
\hline male & $\begin{array}{c}0.345 \\
(0.009)\end{array}$ & $\begin{array}{c}0.346 \\
(0.009)\end{array}$ & $\begin{array}{c}0.348 \\
(0.009)\end{array}$ & $\begin{array}{c}0.325 \\
(0.014)\end{array}$ & $\begin{array}{c}0.344 \\
(0.009)\end{array}$ \\
\hline spouse works & $\begin{array}{l}-0.146 \\
(0.009)\end{array}$ & $\begin{array}{l}-0.147 \\
(0.009)\end{array}$ & $\begin{array}{l}-0.145 \\
(0.009)\end{array}$ & $\begin{array}{l}-0.143 \\
(0.012)\end{array}$ & $\begin{array}{l}-0.142 \\
(0.009)\end{array}$ \\
\hline $\begin{array}{l}\text { fixed effects: } \\
\text { metro status }\end{array}$ & yes & yes & -- & -- & -- \\
\hline SMSA & yes & -- & -- & -- & -- \\
\hline Census region $\times$ year & yes & -- & -- & -- & -- \\
\hline SMSA×year & no & yes & Yes & Yes & Yes \\
\hline SMSA $\times$ metro status $\times$ year & no & no & Yes & Yes & Yes \\
\hline $\begin{array}{l}\text { Observations } \\
\mathrm{R}^{2}\end{array}$ & $\begin{array}{r}40,579 \\
0.282\end{array}$ & $\begin{array}{r}40,579 \\
0.296\end{array}$ & $\begin{array}{r}40,579 \\
0.307\end{array}$ & $\begin{array}{r}18,086 \\
0.341\end{array}$ & $\begin{array}{r}40,579 \\
0.319\end{array}$ \\
\hline
\end{tabular}

Notes: Standard errors, clustered at the household level using the sandwich estimator, are in parentheses. The sample consists of respondents earning at least $\$ 10,000$ residing in a single-family, owner-occupied home. The dependent variable is log real annual wage and the specifications also include age (as a third-order polynomial) and the number of persons in the house. Coefficient estimates not presented here are available upon request. The dummy for shorter commute indicates that the respondent's distance to work is less than the median distance of 10 miles for households that report commuting distance in the AHS.

${ }^{1}$ Omitted category is less than high school.

${ }^{2}$ Metro status is either urban or suburban.

${ }^{3}$ The sample is limited to households that commute more than ten mile to work in order to limit the possibility that localized labor market shocks are affecting the housing market. Also, commuting distance questions were not asked in 1987 so this wave is dropped entirely. 
Table 3: Negative equity and earnings controlling for unobserved heterogeneity in households

\begin{tabular}{|c|c|c|c|c|c|c|}
\hline Variables & $\begin{array}{c}(1) \\
\text { control for } \\
\text { mortgage } \\
\text { characteristics }\end{array}$ & $\begin{array}{c}\text { (2) } \\
\text { Individual } \\
\text { fixed } \\
\text { effects }\end{array}$ & $\begin{array}{l}\text { (3) } \\
\text { IV for } \\
\text { negative } \\
\text { equity }\end{array}$ & $\begin{array}{c}\text { (4) } \\
\text { IV and } \\
\text { Individual } \\
\text { fixed effects }\end{array}$ & $\begin{array}{c}\text { (5) } \\
\text { Low land } \\
\text { value } \\
\text { IV and } \\
\text { Individual } \\
\text { fixed effects }\end{array}$ & $\begin{array}{c}\text { (6) } \\
\text { High land } \\
\text { value } \\
\text { IV and } \\
\text { Individual } \\
\text { fixed effects }\end{array}$ \\
\hline$D^{\text {negative equity }}$ & $\begin{array}{l}-0.071 \\
(0.023)\end{array}$ & $\begin{array}{l}-0.053 \\
(0.020)\end{array}$ & $\begin{array}{l}-0.109 \\
(0.026)\end{array}$ & $\begin{array}{l}-0.057 \\
(0.026)\end{array}$ & $\begin{array}{l}-0.052 \\
(0.045)\end{array}$ & $\begin{array}{l}-0.064 \\
(0.033)\end{array}$ \\
\hline LTV at origination & $\begin{array}{l}-0.000 \\
(0.000)\end{array}$ & & & & & \\
\hline $\begin{array}{l}\text { interest rate at } \\
\text { Origination }\end{array}$ & $\begin{array}{l}-0.007 \\
(0.002)\end{array}$ & & & & & \\
\hline ARM & $\begin{array}{c}0.025 \\
(0.011)\end{array}$ & & & & & \\
\hline second mortgage & $\begin{array}{c}0.032 \\
(0.010)\end{array}$ & & & & & \\
\hline observations & 31,147 & 42,074 & 42,074 & 42,074 & 13,157 & 26,555 \\
\hline $\mathrm{R}^{2}$ & 0.317 & $0.129^{1}$ & 0.306 & $0.129^{1}$ & 0.124 & 0.136 \\
\hline
\end{tabular}

Notes: Standard errors, clustered at the household level using the sandwich estimator, are in parentheses. Negative equity is determined by making different assumptions (as specified in the column title) about the nature of the mortgage(s), then calculating current principal and dividing by self-reported current value. The sample consists of respondents earning at least $\$ 10,000$ residing in a single-family, owner-occupied home. The dependent variable is log real annual wage and the specifications include all covariates from column 3 of Table 2: dummies for educational attainment, sex, race, age (as a third-order polynomial), the number of persons in the house as well as fixed effects for each SMSAxmetro status $\times$ year.

${ }^{1}$ When individual fixed effects are include, the data is de-trended before estimation such that the sum-of-square totals that is the denominator of the $\mathrm{R}^{2}$ ratio is based only on the remaining within individual variation. Thus, the $\mathrm{R}^{2}$ s presented in columns 1 and 3 are not directly comparable to those in 2 and 4. 
Table 4: Negative equity, earnings and immobility

\begin{tabular}{|c|c|c|c|c|c|c|}
\hline & \multicolumn{2}{|c|}{$\begin{array}{c}\text { Are otherwise immobile } \\
\text { households less sensitive to } \\
\text { negative equity? }\end{array}$} & \multirow[b]{2}{*}{$\begin{array}{l}(3) \\
\text { duration in } \\
\text { home }\end{array}$} & \multicolumn{3}{|c|}{ Alternative sources of "house lock" } \\
\hline & $\begin{array}{l}(1) \\
\text { did they } \\
\text { originally } \\
\text { move for } \\
\text { work? }^{1}\end{array}$ & $\begin{array}{l}(2) \\
\text { does spouse } \\
\text { work? }\end{array}$ & & $\begin{array}{l}\text { (4) } \\
\text { nominal loss } \\
\text { aversion }\end{array}$ & $\begin{array}{l}(5) \\
\text { mortgage } \\
\text { lock-in }\end{array}$ & $\begin{array}{l}(6) \\
\text { mortgage } \\
\text { lock-in and } \\
\text { Prop-13 lock- } \\
\text { in }\end{array}$ \\
\hline$D^{\text {negative equity }}$ & $\begin{array}{l}-0.085 \\
(0.024)\end{array}$ & $\begin{array}{l}-0.099 \\
(0.030)\end{array}$ & $\begin{array}{c}-0.084 \\
(0.032)\end{array}$ & $\begin{array}{l}-0.066 \\
(0.025)\end{array}$ & $\begin{array}{l}-0.068 \\
(0.025)\end{array}$ & $\begin{array}{l}-0.068 \\
(0.024)\end{array}$ \\
\hline$D^{\text {moved for work }}$ & $\begin{array}{c}0.099 \\
(0.015)\end{array}$ & & & & & \\
\hline $\begin{array}{l}D^{\text {negative equity }} \\
\times D^{\text {moved for work }}\end{array}$ & $\begin{array}{l}-0.034 \\
(0.096)\end{array}$ & & & & & \\
\hline$D^{\text {spouse works }}$ & & $\begin{array}{l}-0.146 \\
(0.009)\end{array}$ & & & & \\
\hline$D^{\text {negative equity }}$ & & 0.010 & & & & \\
\hline$\times D^{\text {spouse works }}$ & & $(0.042)$ & & & & \\
\hline duration in home & & & $\begin{array}{l}-0.003 \\
(0.006)\end{array}$ & & & \\
\hline$D^{\text {negative equity }}$ & & & -0.003 & & & \\
\hline $\begin{array}{l}\times \text { Duration in } \\
\text { home }\end{array}$ & & & $(0.004)$ & & & \\
\hline$D^{\text {nominal loss }}$ & & & & $\begin{array}{l}-0.039 \\
(0.015)\end{array}$ & $\begin{array}{l}-0.037 \\
(0.014)\end{array}$ & $\begin{array}{l}-0.035 \\
(0.014)\end{array}$ \\
\hline Fixed rate & & & & & 0.034 & 0.033 \\
\hline mortgage lock-in & & & & & $(0.006)$ & $(0.006)$ \\
\hline Proposition-13 tax & & & & & & 0.025 \\
\hline lock in & & & & & & $(0.007)$ \\
\hline Observations & 37,104 & 40,213 & 39,440 & 37,402 & 37,402 & 37,402 \\
\hline $\mathrm{R}^{2}$ & 0.307 & 0.305 & 0.305 & 0.315 & 0.316 & 0.316 \\
\hline
\end{tabular}

Notes: Standard errors, clustered at the household level using the sandwich estimator, are in parentheses. The sample consists of respondents earning at least $\$ 10,000$ residing in a single-family, owner-occupied home. The dependent variable is log real annual and the specifications include all covariates from column 3 of Table 2: dummies for educational attainment, sex, race, age (as a third-order polynomial), the number of persons in the house as well as fixed effects for each SMSA×metro status $\times y e a r$. Negative equity is measured using the synthetic mortgage presented in column 5 of Table 3 which assumes all households take a fixed, 30 year, $80 \%$ LTV loan at the prevailing rate at the time of purchase.

${ }^{1}$ Based on first time household is observed. ${ }^{2}$ Indicates earning more than 10,000 in real 2007 income. 